\title{
PELATIHAN DESAIN GRAFIS UNTUK PERANGKAT DESA DALAM RANGKA PENINGKATAN SDM DI DESA NGAWONGGO KECAMATAN TAJINAN KAB. MALANG
}

\author{
Rini Agustina \\ Fakultas Sains dan Teknologi Universitas Kanjuruhan Malang \\ riniagustina@unikama.ac.id
}

\begin{abstract}
Abstrak
Perkembangan teknologi yang semakin pesat sangat berpengaruh terhadap lembaga pelayanan masyarakat ditingkat desa. Desa saat ini telah melakukan banyak peningkatan dalam hal pelayanan kepada masyarakat, termasuk salah satunya adalah pelayanan dalam hal pemberian informasi. Informasi dari pusat harus segera bisa diserap oleh masyarakat secepatnya mengingat adanya tenggat waktu dan masa di setiap informasi yang disampaikan. Informasi yang diberikan akan sangat berguna bagi masyarakat untuk itu perlu adanya sosialisasi secara cepat dan tepat.

Sosialisasi di desa yang belum mengenal adanya internet sedikit mengalami kelambatan karena media penyebaran informasi yang masih bersifat kontekstual/ tertulis. Adapun pembuatan media untuk menyampaikan informasi ini juga terkendala karena sumber daya manusia (SDM) yang kurang bisa membuatnya dengan cepat dan menarik, sehingga masyarakat tidak tertarik untuk membaca informasi yang telah dipasang atau ditempelkan pada papan pengumuman. Menjawab permasalahan tersebut SDM dari perangkat desa dilatih membuat desain grafis untuk meningkatkan kreatifitas dari perangkat desa.
\end{abstract}

Kata Kunci : Pelatihan, SDM, Corel Draw.

\section{PENDAHULUAN}

\section{a. Analisis Situasi}

Perkembangan teknologi informasi dan komunikasi dewasa ini telah berkembang sangat pesat dan hampir telah mempengaruhi semua aspek kehidupan manusia. Dalam era teknologi informasi ini ditandai dengan kecepatan dan kemudahan untuk mendapatkan informasi yang dibutuhkan.

Perkembangan yang terjadi juga sangat berpengaruh terhadap lembaga pelayanan masyarakat ditingkat desa. Desa saat ini telah melakukan banyak peningkatan dalam hal pelayanan kepada masyarakat, termasuk salah satunya adalah pelayanan dalam hal pemberian informasi. Informasi dari pusat harus segera bisa diserap oleh masyarakat secepatnya mengingat adanya tenggat waktu dan masa di setiap informasi yang disampaikan. Informasi yang diberikan akan sangat berguna bagi masyarakat untuk itu perlu adanya sosialisasi secara cepat dan tepat.

Menyiasati hal tersebut perangkat desa dan pimpinan mencoba melakukan kreatifitas dengan menambahkan beberapa hiasan untuk menarik minat masyarakat membaca informasi yang disampaikan, selain itu juga menggerakkan masyarakat untuk lebih kreatif dalam usaha mandiri dibidang desain. Desain yang diinginkan selain untuk menampilkan informasi juga digunakan untuk keperluan lain seperti pembuatan pamflet lomba, bazar, kegiatan posyandu, maupun kegiatan perayaan hari kemerdekaan.

\section{b. Permasalahan Mitra}

Permasalahan di Desa Ngawonggo adalah kurangnya kreatifitas dari perangkat desa dalam membuat media untuk menyampaikan informasi kepada masyarakat, serta kegiatan desa lainnya dalam usaha untuk mempromosikan suatu kegiatan.

\section{c. Solusi yang ditawarkan}

Solusi yang ditawarkan adalah memberikan pelatihan desain grafis untuk perangkat desa Ngawonggo kecamatan Tajinan Kabupaten Malang.

\section{d. Target}

Target yang diharapkan pada pengabdian masyarakat ini sesuai dengan permintaan dari Kepala Desa yaitu para Perangkat desa mampu membuat media informasi dengan lebih baik bagi masyarakat untuk meningkatkan proses transfer informasi di wilayah desa.

Penyampaian informasi oleh Perangkat Desa diharapkan mampu memberikan kontribusi nyata terhadap meningkatkan kualitas informasi di seluruh pelosok desa.

Melalui pelatihan ini Perangkat Desa Ngawonggo diharapkan mampu menggunakan aplikasi Corel Draw untuk membuat media informasi 
sekaligus mengaplikasikannya untuk kegiatan seharihari di lingkungan desa.

\section{e. Luaran}

Luaran pelatihan ini berupa file pembuatan media informasi yang dibuat oleh para perangkat desa untuk masyarakat. Media berisi informasi kegiatan umum di desa seperti posyandu, karang taruna, kegiatan warga, dan lain-lain.

\section{METODE KEGIATAN}

Pelaksanaan kegiatan pengabdian meliputi pelatihan yang diberikan secara langsung dan pendampingan step by step selama pembuatan media pembelajaran. Adapun ringkasan dari permasalahan dan solusi yang diberikan dapat dilihat pada Tabel 3.1 sebagai berikut:

Tabel 3.1 Permasalahan, Solusi dan Metode Pemecahan Masalah

\begin{tabular}{|c|c|c|c|}
\hline No & $\begin{array}{c}\text { Permasalahan } \\
\text { Mitra }\end{array}$ & Solusi & Metode \\
\hline 1 & $\begin{array}{l}\text { Perangkat Desa } \\
\text { kesulitan dalam } \\
\text { menyampaikan } \\
\text { informasi kepada } \\
\text { masyarakat seputar } \\
\text { program-program } \\
\text { dari pemerintah, } \\
\text { karena kurang } \\
\text { tertariknya } \\
\text { masyarakat akan } \\
\text { media yang } \\
\text { dipergunakan. }\end{array}$ & $\begin{array}{l}\text { Pelatihan } \\
\text { menggambar } \\
\text { dan mendesain } \\
\text { objek informasi } \\
\text { dengan } \\
\text { menggunakan } \\
\text { Corel Draw. }\end{array}$ & $\begin{array}{l}\text { Presentasi, } \\
\text { Praktek } \\
\text { Langsung, } \\
\text { Diskusi }\end{array}$ \\
\hline 2 & $\begin{array}{l}\text { Informasi yang } \\
\text { disajikan kurang } \\
\text { menarik dan tidak } \\
\text { semua orang bisa } \\
\text { memahami maksud } \\
\text { dari informasi yang } \\
\text { ada. }\end{array}$ & $\begin{array}{l}\text { Pelatihan } \\
\text { membuat desain } \\
\text { dengan } \\
\text { menggunakan } \\
\text { kalimat yang } \\
\text { lebih sederhana } \\
\text { dan } \\
\text { menyajikannya } \\
\text { dengan lebih } \\
\text { menarik. }\end{array}$ & $\begin{array}{l}\text { Presentasi, } \\
\text { Praktek } \\
\text { Langsung, } \\
\text { Diskusi }\end{array}$ \\
\hline 3 & $\begin{array}{l}\text { Program-program } \\
\text { kerja dari } \\
\text { pemerintah tidak } \\
\text { mendapatkan respon } \\
\text { yang cukup dari } \\
\text { warga. }\end{array}$ & $\begin{array}{l}\text { Pembuatan } \\
\text { desain yang } \\
\text { lebih atraktif } \\
\text { dengan } \\
\text { menambahkan } \\
\text { beberapa objek } \\
\text { gambar yang } \\
\text { sesuai dengan } \\
\text { topik informasi. }\end{array}$ & $\begin{array}{l}\text { Presentasi, } \\
\text { Praktek } \\
\text { Langsung, } \\
\text { Diskusi }\end{array}$ \\
\hline
\end{tabular}

\section{Evaluasi Kegiatan}

Evaluasi Pelaksanaan kegiatan Pengabdian Masyarakat ini dilakukan oleh tim pelaksana dengan detail kegiatan sebagai berikut :

a. Tim pelaksana akan memantau kehadiran dan keaktifan setiap peserta melalui pengecekan presensi kehadiran. Kriteria pengukuran keberahasilan PPM adalah : (1) $100 \%$ peserta hadir mengikuti pelatihan. (2) $90 \%$ peserta yang hadir Aktif mengikuti kegiatan.

b. Beradasarkan jadwal pelaksana kegiatan, tim pelaksana akan melakukan peninjauan ulang terhadap keseuaian jadwal kegiatan, alokasi waktu, materi kegiatan serta metode yang telah dirancang.

\section{HASIL DAN PEMBAHASAN}

Ilmu Grafis Tutorial Memulai CorelDraw untuk pemula berisi pengenalan dan panduan dasar dalam belajar komputer desain. Sebelum kita memulainya tutorial CorelDraw akan lebih baik jika kita mengetahui apa saja yang terkandung didalamnya. Coreldraw adalah pengolah Vektor berupa garis dan bidang yang diolah berdasarkan pengaturanpengaturan angka-angka vektor.

Pada pengenalan ini kita akan mempelajari lebar kerja atau tampilan CorelDraw. Di sini saya menggunakan CorelDraw Graphic Suite X4 yang pada dasarnya hampir sama dengan CorelDraw pendahulunya yaitu X3, CorelDraw 10, 11, dan 12 . Kemiripan ini dikarenakan agar para pengguna CorelDraw tidak canggung untuk menghadapi perubahan pada setiap versi. Untuk langkah cepat kita akan memulai dari awal apa saja yang ada di dalam CorelDraw.

\section{Memulai CorelDraw}

1. Klik tombol Start $>$ Program $>$ Corel Graphic Suite X4 > Corel Draw

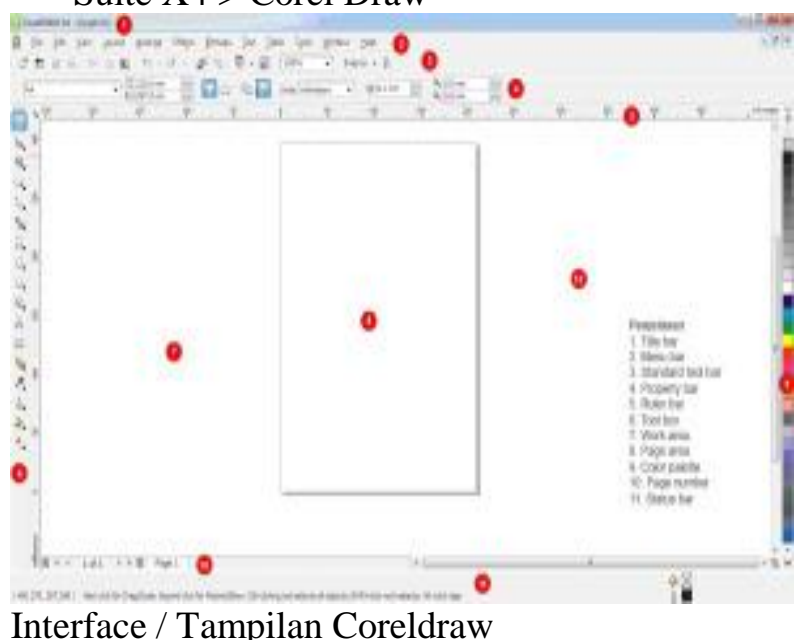

Interface / Tampilan Coreldraw

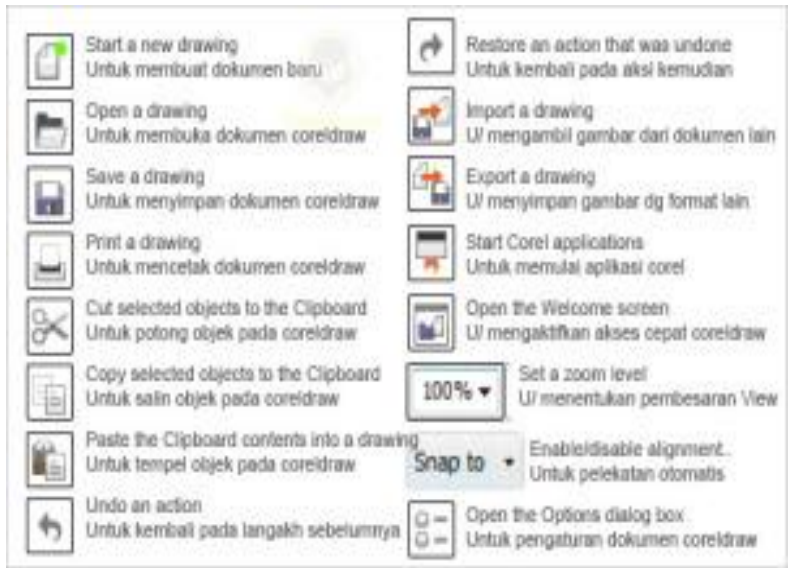

Peralatan untuk mendesain di CorelDraw semua terdapat pada tool box (lihat interface pada point 6). Ada beberapa tool yang mempunyai tombol flyout 
(panah kanan bawah) yang berisi beberapa tool lainnya. Flyout selengkapnya ada pada gambar berikut:

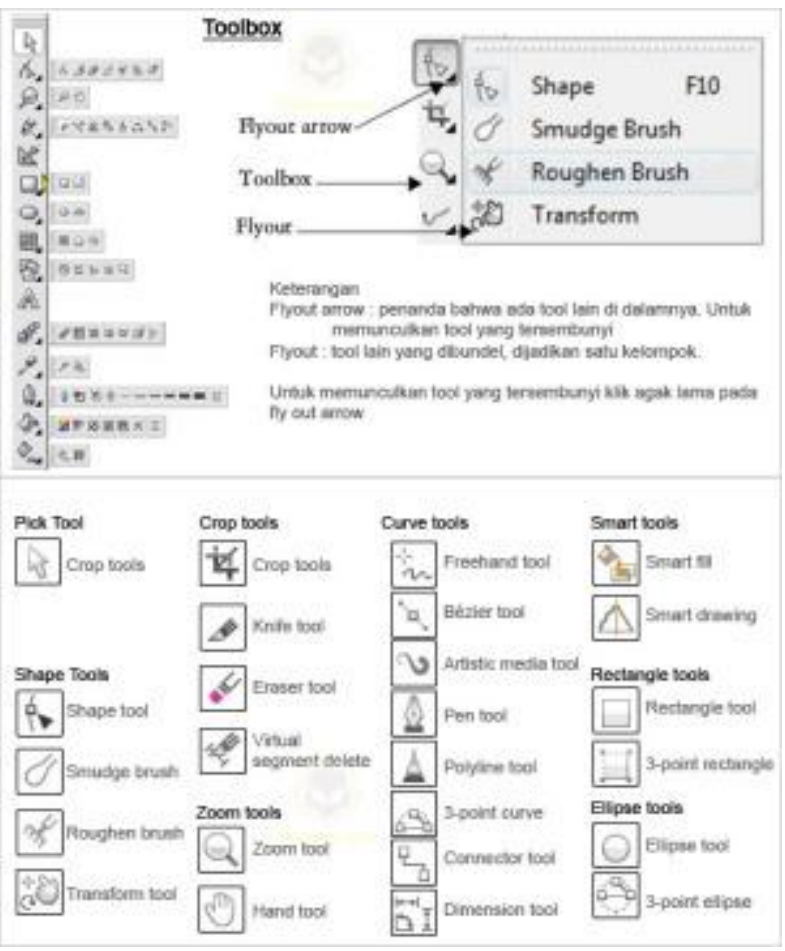

\section{Penjelasan}

1. Pick tool: Mengaktifkan obyek dan untuk melakukan editing dasar dari obyek. Misalnya scaling, rotating, skewing, resizing

\section{Shape Tools}

1. Shape Tool: Melakukan proses editing node pada shape( komponen garis dari obyek).

2. Smudge Tool: Menggosok obyek sehingga merubah bentuk obyek yang digosok tersebut.

3. Roughen Tool: Memberikan efek distorsi pada obyek.

4. Transform Tool: Merotasi, membesarkan, mengecilkan, skewing image secara bebas.

\section{Crop Tools}

1. Crop Tool: Digunakan untuk menghapus objek diluar seleksi.

2. Knife Tool: Pisau yang berfungsi untuk memotong obyek. Cara kerjanya persis seperti menggunakan pisau biasa.

3. Eraser Tool: Menghapus bagian tertentu dari obyek.

4. Virtual Segment delete tool: Menghapus segmen secara virtual

\section{Zoom Tools}

1. Zoom Tool: Membesarkan atau mengecilkan tampilan area kerja di monitor.

2. Hand Tool: Menggeser area kerja ke posisi tertentu.

\section{Curve Tools}

1. Freehand Tool: Membuat obyek berupa garis bebas.

2. Bezier Tool: Membuat obyek garis dengan menentukan banyaknya node.

3. Artistic Media Tool: Membuat obyek garis dengan berbagai bentuk yang artistik.

4. Pen Tool: Membuat obyek kombinasi antara garis lurus dan garis lengkung secara langsung.

5. Polyline Tool: Membuat obyek kombinasi garis lurus dan freehand secara langsung.

6. 3-Point Tool: Membuat obyek garis dengan kurva 3 point.

7. Connector Tool: Membuat obyek garis konektor secara interaktif

8. Dimension Tool: Membuat obyek garis ukuran pada suatu obyek yang kita buat.

\section{Smart Tools}

1. Smart Fill: Untuk mewarna objek dan garis secara bersamaan sesuai dengan pengaturan.

2. Smart Drawing : Membuat obyek garis secara bebas seperti freehand tool, namun dengan hasil yang lebih bagus.

\section{Rectangle Tools}

1. Rectangle Tool: Membuat obyek persegi panjang atau bujur sangkar.

2. 3-Point Rectangle Tool: Membuat obyek persegi panjang atau bujur sangkar dengan kemiringan tertentu.

\section{Ellipse Tools}

1. Ellipse Tool: Membuat obyek lingkaran atau elips.

2. 3-Point Ellipse Tool: Membuat obyek lingkaran atau elips dengan kemiringan tertentu.

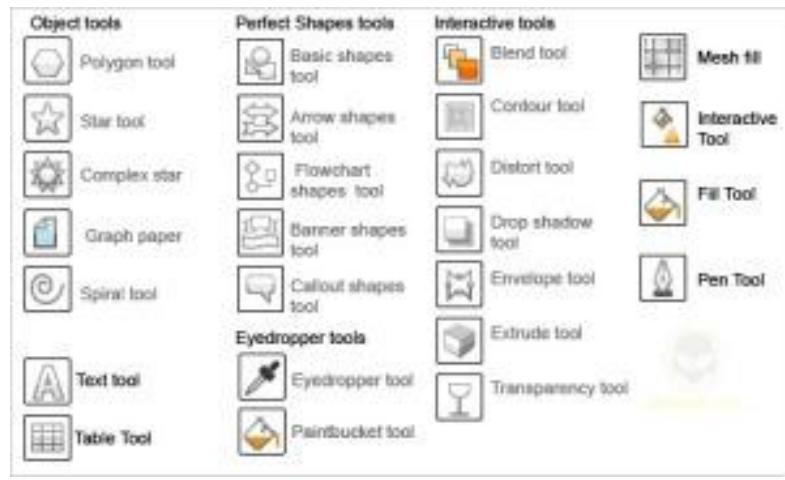

\section{Penjelasan}

\section{Object Tools}

1. Polygon Tool: Membuat obyek segi banyak.

2. Star Tool: Membuat obyek-obyek bintang.

3. Complex Star Tool: Membuat obyek-obyek bintang sudut banyak. 
4. Graph Paper: Membuat obyek menyerupai tabel.

5. Spiral Tool: Membuat obyek spiral.

6. Text Tool: Membuat obyek teks.

7. Table Tool: Membuat tabel.

\section{Perfect Shape Tools}

1. Basic Shapes Tool: Membuat obyek-obyek dasar.

2. Arrow Shapes Tool: Membuat obyek-obyek anak panah.

3. Flowchart Shapes Tool: Membuat obyekobyek flowchart.

4. Banner Shapes Tool: Membuat objek-objek banner.

5. Callout Shapes Tool: Membuat obyek-obyek callout (objek isi teks pada komik).

\section{Eyedropper Tools}

1. Eyedropper tool: Mengambil sampel warna dari suatu obyek.

2. Paintbucket tool: Memberikan warna tertentu pada suatu obyek.

\section{Interactive Tools}

1. Blend tool: Memberikan efek transformasi dari satu obyek ke obyek lain.

2. Contour tool: Memberikan efek kontur pada obyek.

3. Distort tool: Memberikan efek distorsi pada obyek.

4. Drop shadow tool: Memberikan efek bayangan pada obyek.

5. Envelope tool: Memberikan efek perubahan bentuk pada obyek.

6. Extrude tool: Memberikan efek tiga dimensi pada obyek.

7. Transparency tool: Memberikan efek transparansi warna pada obyek.

\section{Interactive Fiil Tools}

1. Fill tool : Mewarna objek dengan macam-macam metode.

2. Mesh fiil tool: Mewarna bidang pada objek.

\section{Outline Tools}

1. Outline color dialog: Memunculkan color outline tool.

2. No outline: Menghilangkan outline.

3. Hairline outline: Memberikan outline dengan ukuran sangat kecil.

4. $1 / 2$ point outline: Memberikan ukuran outline $1 / 2$ poin.

5. 1 point outline: Memberikan ukuran outline1 poin.

6. 2 point outline: Memberikan ukuran outline2 poin.
7. 8 point outline: Memberikan ukuran outline8 poin.

8. 16 point outline : Memberikan ukuran outline16 poin.

9. 24 point outline: Memberikan ukuran outline24 poin.

10.Color docker window: Memunculkan color docker window untuk outline.

11.Fill color dialog: Memunculkan kotak dialog warna isi.

12.Fountine fill dialog: Memunculkan kotak dialog warna gradasi

13.Pattern fill dialog: Memunculkan kotak dialog pola.

14.Texture fill dialog: Memunculkan kotak dialog tekstur.

15.Postscript fill dialog : Memunculkan kotak dialog postscript.

16.No fill : Menghilangkan warna isi.

17. Color docker dialog: Memunculkan color docker window untuk warna isi.

\section{Property Bar}

Property bar adalah fasilitas yang disediakan untuk memunculkan fungsi-fungsi yang sering digunakan ketika aktif pada salah satu alat gambar pada tool box. Isi dari property bar akan menyesuaikan dengan salah satu alat yang sedang aktif pada tool box. Pengaturan halaman bisa dilakukan melalui Property Bar pada saat Pick Tool dan berikut ini adalah salah satu fungsi yang muncul pada property bar ketika mengaktifkan text tool:

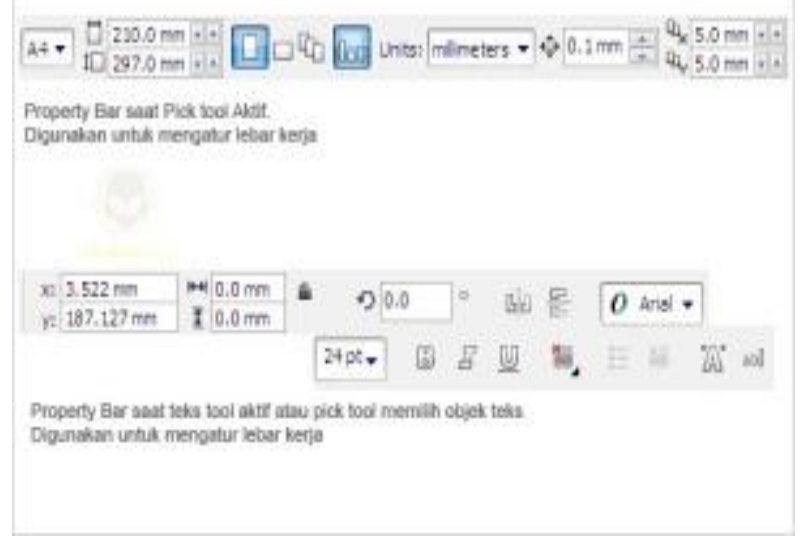

\section{Pengaturan sebelum mendesain}

Sebelum kita mulai mendesain, sebaiknya kita atur dulu halaman yang akan kita gunakan. Pengaturan halaman tersebut meliputi pemilihan jenis kertas, ukuran kertas, orientasi kertas, satuan ukuran yang akan digunakan dan lain-lain. Klik Menu Tool > Options maka akan muncul window seperti berikut: 


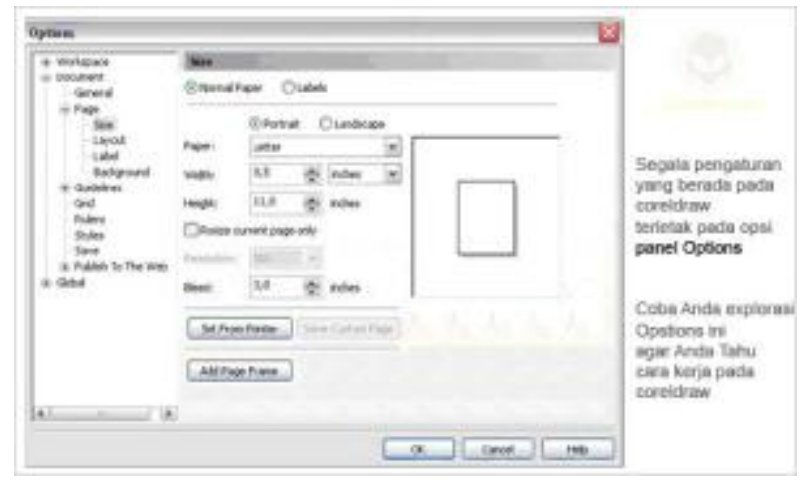

\section{Indikator Keberhasilan}

Hasil yang diperoleh dalam pelatihan ini adalah adanya peningkatan pengetahuan dan informasi peserta mengenai teknologi informasi, serta meningkatnya kompetensi dari para peserta dalam hal pembuatan media informasi.

\section{Kontribusi Mitra}

Pada kegiatan ini Desa Ngawonggo menyediakan sarana pelatihan berupa LCD, Mic, Laptop, Software dan materi pendukung lainnya. Teknis pelaksanaan juga dilakukan oleh pihak desa dengan sangat baik, seperti tempat, waktu dan konsumsi.

Sebagai obyek kegiatan para peserta memberikan dukungan yang cukup baik sehingga sebagai pemateri merasakan adanya feed back yang sangat menyenangkan. Sedangkan sebagai subyek penelitian para peserta bersedia menyediakan waktu dan tenaga sebagai peserta pelatihan serta aktif mengikuti kegiatan.

\section{Keberlanjutan}

Permintaan akan keberlanjutan program pelatihan dari para guru dan Kepala sekolah merupakan salah satu alasan kenapa pelatihan ini didesain secara bertahap. Selain sebagai media transfer knowledge juga sebagai media transfer teknologi yang sudah menjadi kewajiban bagi pemateri.

\section{Dokumentasi Kegiatan}

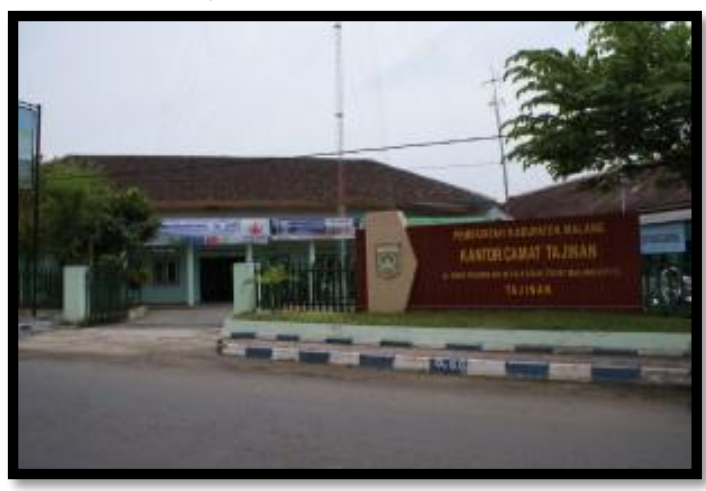

Sumber: https://desangawonggo.wordpress.com/

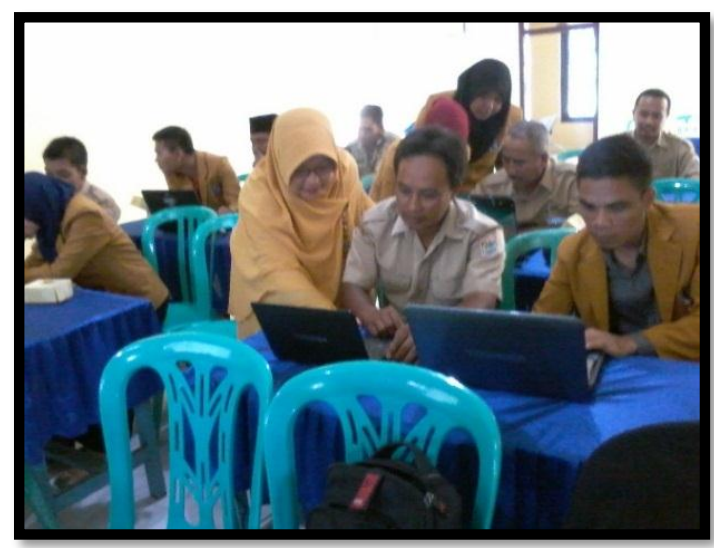

Sumber : Penulis
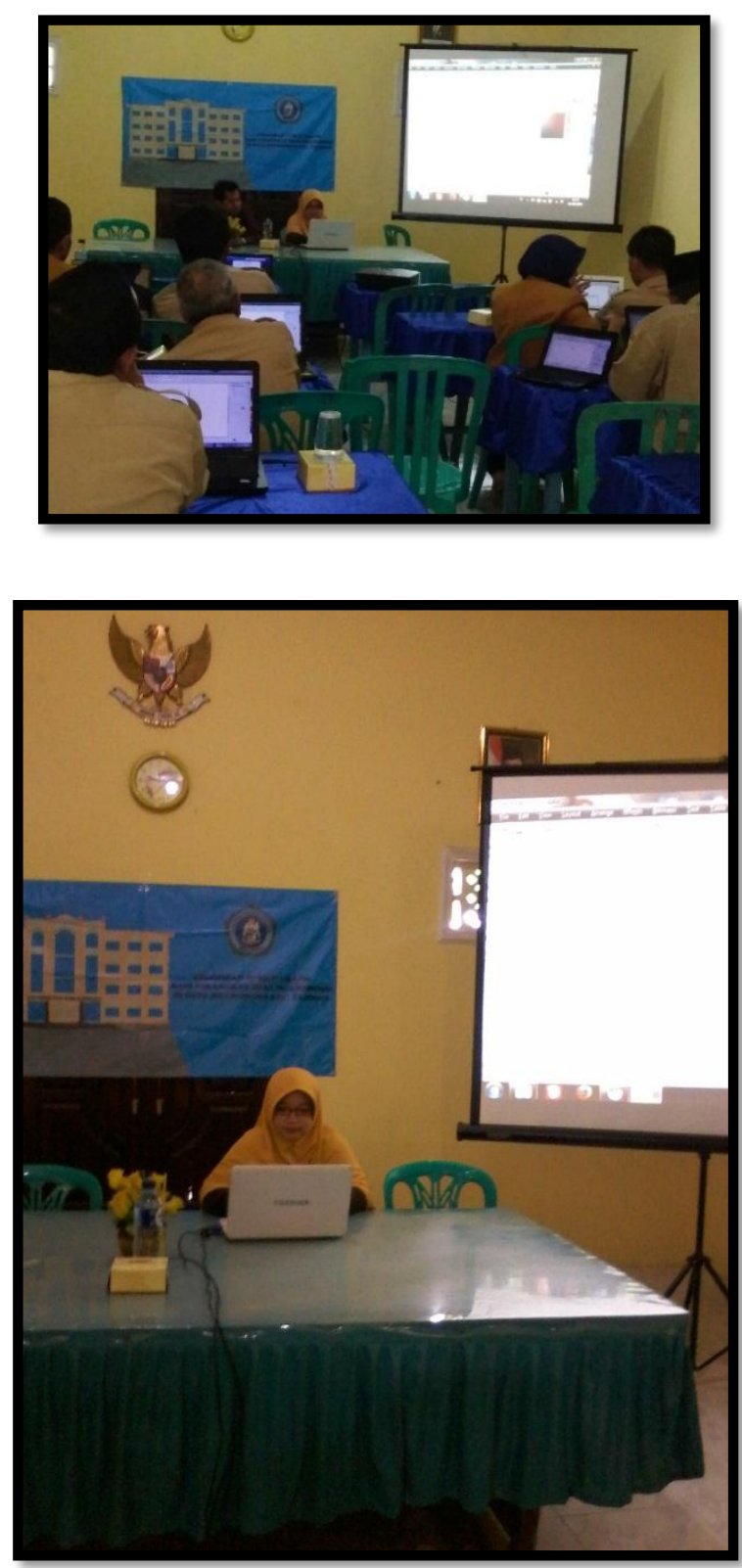

Sumber: Penulis 


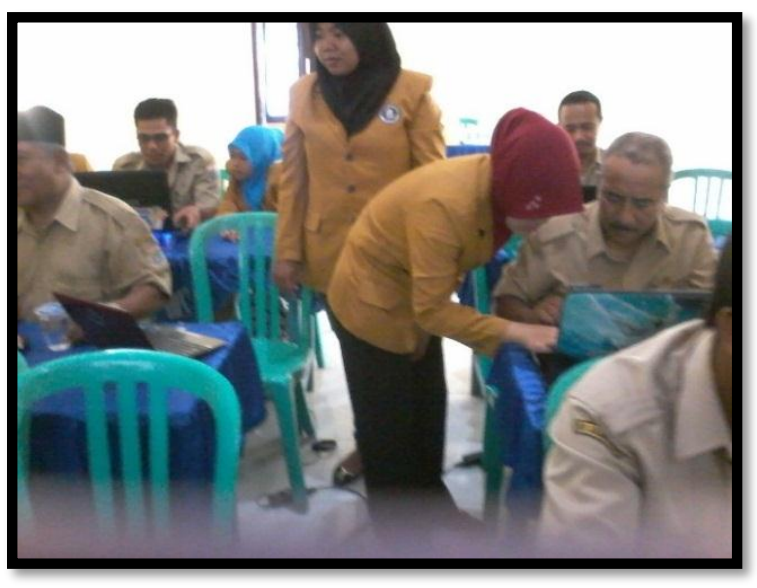

Sumber: Penulis

\section{KESIMPULAN}

\section{a. Kesimpulan}

Dari Uraian di atas maka dapat disimpulkan sebagai berikut :

1. Pelaksanaan Pengabdian Pada Masyarakat pada pelatihan untuk Perangkat Desa Ngawonggo Kecamatan Tajinan Kabupaten Malang berlangsung dengan baik sesuai dengan rencana umum.

2. Pelaksanaan Pengabdian Pada Masyarakat ini dinyatakan berhasil mencapai tujuan dan target.

3. Peserta Pengabdian Pada Masyarakat termotivasi secara aktif dalam mengikuti kegiatan sampai tuntas.

\section{b. Saran}

1. Untuk penyempurnaan pelaksanaan Pengabdian Pada Masyarakat ini secara maksimal, maka sangat di harapkan pembinaan lebih lanjut kepada peserta secara berkelanjutan oleh LPPM Universitas Kanjuruhan malang.

2. Pengabdian pada Masyarakat secara berkelanjutan perlu menjadi prioritas utama pada kegiatan berikutnya dengan memberikan materi-materi tambahan sesuai dengan perkembangan teknologi yang terbaru.

\section{REFERENSI}

Gomes (1997 : 197), Manajemen Sumber Daya Manusia, (Online) http://jurnalsdm.blogspot.com/2009/04/ pelatihan-kerjadefinisi-tujuan-teknik.html

Gary Dessler (1997:263), Pelatihan, (online) http://id.wikipedia.org/wiki/ Pelatihan.

John R. Schermerhorn, Jr (1999:323), Definisi Pelatihan, (online) http://percik cahaya.blogspot.com/2011/09/ pelatihan.html

Hersey dan Blanchart (1992: 5), Situational Leadership, (online) http://teorionline .net/situational-leadership-hersey-blanchard/

Hariandja (2002:168), Pentingnya Pelatihan, (online) http://trustbimoindonesia .com/?p=29ada

Manullang (1990:47) program pelatihan, http://aakhamza.blogspot.com/2010/11/proposalpengaruh-pelaksanaan-program.html

Moekijat (1991:55), Tujuan Pelatihan, (online) http://percikcahaya.blogspot.com/2011/09/pelati han. html

Program latihan menurut Handoko (1995:110), Program Latihan, (online) http://sitiativa.wordpress.com/ 2012/09/09/pendidikan-keaksaraan-danpendidikan-keterampilan-dan-pelatihan-kerja-2/

Staf, 2009, Definisi pelatihan, (online) http://jurnalsdm.blogspot.com/2009/04/pelatihan-kerjadefinisi-tujuan-teknik.html.

Staf, 2004, Pengertian Corel Draw, (online) https://tugasdesaintgi.wordpress.com/2013/10/30 /pengenalan-coreldraw/comment-page-1/

Soeprihanto (1997:24), http://suempalette81. blogspot. com/2012/03/aktivitas-manajemensdm-untuk.html 